\title{
Metallothionein analysis and cell damage levels on the liver and gill of Barbonymus gonionotus In Brantas River, Indonesia
}

\author{
Alfiah Hayati*, Nita Yuliarini, Agoes Soegianto, Hana Widyana, Inesavira Rindaputri, Nuris Auliya, Putri Ayu Ika \\ Department of Biology, Faculty of Science and Technology, Universitas Airlangga
}

\begin{abstract}
This study aimed to analyze the levels of metallothionein and damage to hepatocytes and gills of Barbonymus gonionotus in the Brantas River (upstream and downstream), and the correlation levels of metallothionein in the gills and liver of Barbonymus gonionotus with different sampling time variation (March, June, and September 2016). Fishes were caught using trawl in two stations (Karangkates Reservoir and the Kali Jagir river). Fish gills and livers were taken for histopathological analysis and levels of metallothionein were measured by ELISA method. Gills histopathological analysis showed that the highest damage in Karangkates reservoir dan Kali Jagir river is hyperplasia. Liver histopathological analysis in Karangkates reservoir showed normal hepatocytes meanwhile necrosis is highest damage found in Kali Jagir river. Metallothionein levels of fish in Karangkates reservoir for March, June, and September were $0.18 \mathrm{ng} / \mathrm{mL} ; 0,18 \mathrm{ng} / \mathrm{mL}$; and $0.2 \mathrm{ng} / \mathrm{mL}$ (gills fish); $0,18 \mathrm{ng} / \mathrm{mL} ; 0,34 \mathrm{ng} / \mathrm{mL}$; and 0,21 ng/mL (liver fish) respectively. Metallothionein levels of fish in Kali Jagir river for March, June, and September were $0,26 \mathrm{ng} / \mathrm{mL} ; 0,18 \mathrm{ng} / \mathrm{mL}$; and $0,18 \mathrm{ng} / \mathrm{mL}$ (gills fish); $0,2 \mathrm{ng} / \mathrm{mL} ; 0,45 \mathrm{ng} / \mathrm{mL} ; 0,19 \mathrm{ng} / \mathrm{mL}$ (liver fish) respectively. We conclude that the damage to the gills and liver of Barbonymus gonionotus was mostly found in Kali Jagir River and the highest metallothionein level of Barbonymus gonionotus also presented in Kali Jagir River.
\end{abstract}

Keywords: Brantas River, Barbonymus gonionotus, histopathology, Karangkates reservoir, Kali Jagir river, metallothionein.

Received: 11 October 2017 Revised: 31 October 2017 Accepted: 05 November 2017

\section{Introduction}

Water pollution disrupt and decrease biota diversity. Environmental damage as response to water pollution has become the main concern in recent years (Authman et al., 2013). Brantas River is the second longest river in East Java, after Bengawan Solo River. Brantas River watershed is beneficial for water debit control, irigation, hydroelectric power plant (PLTA), drinking water, fishery, and recreation (Usman., 2003). Increasing number of human population in the riverbank of Brantas River and waste disposal from industrial activity contribute to higher level of pollution (Hayati et al., 2017). Brantas River is polluted by heavy metal elements $(\mathrm{Pb}, \mathrm{Cu}, \mathrm{Cr}$, and $\mathrm{Cd})$ which can be absorbed by organism and bind the receptor in the cell (Hayati et al., 2017).

Metallothionein (500-14000 Da) is localized in golgi apparatus membrane. It able to bind high amount of heavy metals through thiol group (Sulfhyhydryl, -SH) from cysteine residue due to high amount of amino acid Cys (Sigel, 2009). Metallothionein induction depends on the amount of oxidative heavy metals and glucocorticoids in the body. In general, high amount of metallothionein is synthesized in liver and kidney as scavanger in the cell due to the existence of cysteynil thiolate group (Nedeckey et al., 2013).

Fish are relatively sensitive to environmental changes, have relatively long life, and have risk of heavy metal accumulation in their body (Wangboje et al., 2013). Heavy metal absorption in aquatic organism increases with increasing trophic level in ecosystem (Soegianto.,

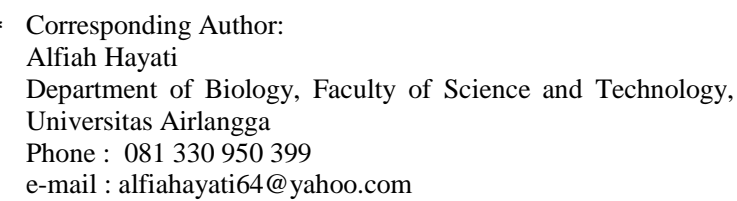

2008). Fish that are mostly found in Brantas River is Barbonymus gonionotus, and this kind of fish is consumed by people (Priatna et al., 2016). Heavy metal concentration $(\mathrm{Pb}, \mathrm{Cr}, \mathrm{Cu}$, and $\mathrm{Cd})$ in the water of the upstream (Karangkates Reservoir) and the downstream (Kali Jagir River) has reached more than $0.03 \mathrm{ppm}$ (Hayati et al., 2017), which means it exceeds the maximum limit allowed by the Regulation of Health Minister No. 492/2010. The cell should keep the homeostatic in the fish body to prevent any free radicals that may lead to oxidative stress (Annabi et al., 2013).

However, few studies were conducted on histopathology and metallothionein level of Barbonymus gonionotus habitated in the upstream (Karangkates Reservoir) and downstream (Kali Jagir River), so further observation study was needed to analyze the histopathology and metallothionein levels in the gill, liver, and meat of Barbonymus gonionotus taken from the upstream (Karangkates Reservoir) and downstream (Kali Jagir River, Surabaya). It is also beneficial to acknowledge the quality of Barbonymus gonionotus in Karangkates Reservoir and Kali Jagir River because this fish is highly consumed.

\section{Method}

\section{Agreement on Code Ethic \\ Not done in this research}

\section{Sampling}

The sample of Barbonymus gonionotus was taken on March to September 2016 using trawl net. For each station, 2 fishes were taken (on March, June, September), so the total number of fishes from the upstream and downstream were 12 . Then, fishes were dissected for their 
gills and livers, kept in an ice box, and moved into a freezer at $-20^{\circ} \mathrm{C}$ until the examination time.

\section{Histopathological Analysis}

After section staining, slides were covered, glued by entellan and observed later. The observation was done by investigating which parts of hepatocytes were normal, had hypertrophy and had necrosis within five fields of vision as the replication of observation using graticule. Histopathological analysis $(\%)=[$ (number of necrosis cells) / (total number of cells)] x $100 \%$.

\section{Protein Isolation}

$0.5 \mathrm{~g}$ of organ samples (gill and liver) were washed with PBS 3 times and crushed in a mortar on an ice tray. In the mortar, $1 \mathrm{~mL}$ of extraction buffer $(1 \mathrm{mM}$ PMSF in DMSO $100 \mu \mathrm{l}, 50 \mathrm{mM} \mathrm{KH_{2 }}$ PO4 with pH $4500 \mu 1,0,5 \%$ Nonidet P-40 $5 \mu \mathrm{l}$, Aquabides $345 \mu \mathrm{l}$ ) was added to sample and homogenized. The homogenate was poured into microtube $1,5 \mathrm{~mL}$ and centrifuged (Hettich zentrifugen, Germany) at $10,000 \mathrm{rpm}, 4{ }^{\circ} \mathrm{C}$ for 20

\section{Results}

Histopathological Analysis on the Gills of Barbonymous gonionotus in Karangkates Reservoir and Kali Jagir River.

The gill lamella of Barbonymous gonionotus in Karangkates Reservoir on March, June, and September 2016 have been damaged. The mostly found damage was hyperplasia. However, there was different number of hyperplasia in Karangkates Reservoir. The number of hyperplasia on March 2016 (50.86\%) was the lowest hyperplasia compared to number of hyperplasia on June and September 2016. There was also rising number of hyperplasia from March to September 2016. This result minutes. Then, pellets were removed. The supernatant was moved to a new microtube $1,5 \mathrm{~mL}$ and kept at $4{ }^{\circ} \mathrm{C}$ until being used (Fatchiyah et al., 2011).

\section{Elisa Sandwich Method}

$50 \mu$ of standard solution was added into standard wells (no other solution was added into the control wells). $40 \mu \mathrm{l}$ of sample and $10 \mu \mathrm{l}$ of antibody were added into the sample wells. $50 \mu \mathrm{l}$ of streptavidin HRP was mixed in each well. Plate was closed with alumunium foil and incubated for 60 minutes at $37{ }^{\circ} \mathrm{C}$. Plate was washed 5 times with washing buffer. The wells were soaked in 0,35 washing buffer for 1 minute. Then, $50 \mu 1$ substrate solution A and substrate solution B were added to each well and incubated for 10 minutes at $37{ }^{\circ} \mathrm{C}$ without light. $50 \mu \mathrm{l}$ of stop solution was added to each well and the color of wells will be changed from blue to yellow. After 30 minutes of stop solution addition, absorbance was measured using microplate ELISA reader at $450 \mathrm{~nm}$ (KIT ELISA procedure, cat No:E0005Fi).

was associated with increasing of pollution level in Karangkates Reservoir from March to September 2016.

The gill lamella of Barbonymous gonionotus in Kali Jagir River on March, June, and September 2016 also have been damaged. The mostly found damage was hyperplasia. Different number of hyperplasia in Kali Jagir River were showed. The number of hyperplasia on June $2016(88.06 \%)$ was the lowest hyperplasia compared to hyperplasia happened on March and September 2016. The number of hyperplasia was decreased from March to June but increased on September 2016. From those three periods of time, the highest number of hyperplasia was on September 2016 due to the fact that pollution level was increased in Kali Jagir River on that month. So the number of hyperplasia also increased.

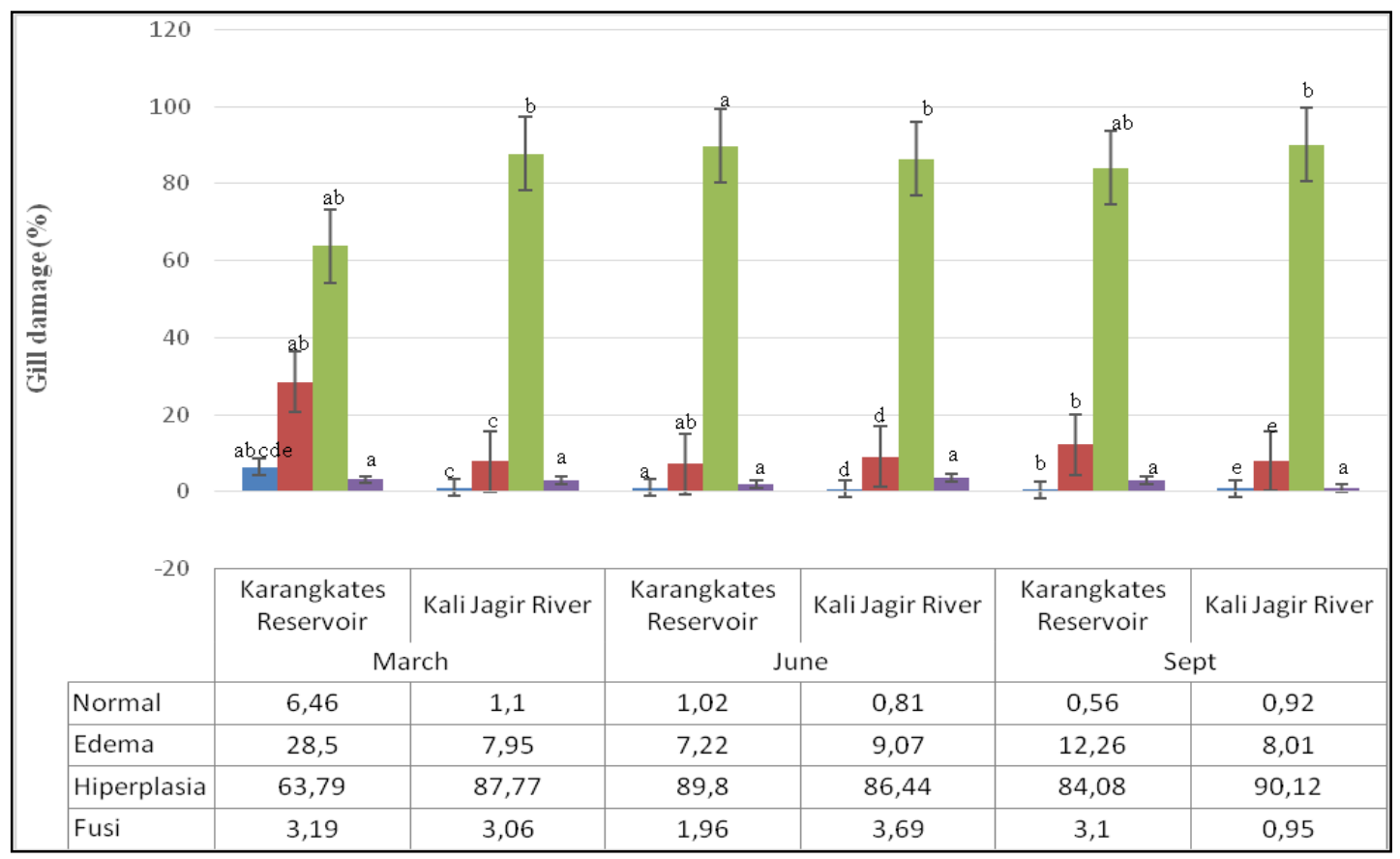

Figure 1. Histopathological analysis of Barbonymous gonionotus gill in the upstream and downsteram of Brantas River 
Hispathological Analysis on Hepatocytes of Barbonymous gonionotus in Karangkates Reservoir and Kali Jagir River.

This present result showed that the highest number of hepatocytes in Karangkates Reservoir were normal hepatocytes. The highest percentage of normal hepatocytes was on March as response to low pollution level in Karangkates Reservoir on March 2016 (3,11\%). The number of normal hepatocytes on June started to decrease because of pollution level rising in Karangkates Reservoir. The lowest number of normal hepatocytes in Karangkates Reservoir was on September $(39,89 \%)$.

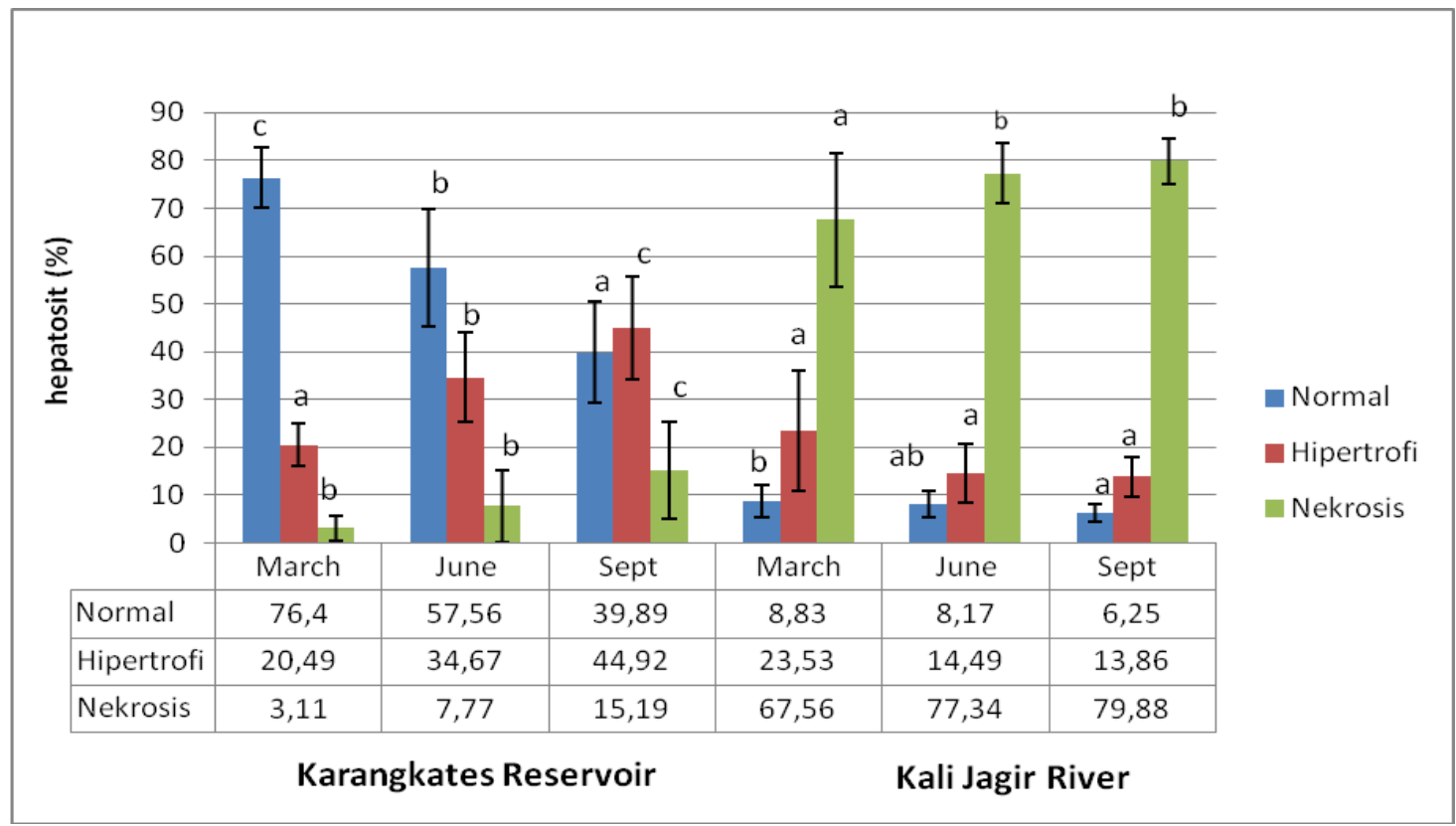

Figure 2. Histopathological analysis of Barbonymous gonionotus liver in the upstream and downstream of Brantas River

Metalothionein levels on the Gills and Liver of Barbonymus gonionotus in the Upstream (Karangkates Reservoir) and Downstream (Kali Jagir River) of Brantas River

The result of metallothionein levels in the gills and liver measured with ELISA method was shown in Table 1.

The comparative analysis of metallothionein levels on the gills and liverof the fish showed significantly difference between metallothionein levels in the upstream and downstream of Brantas River. The different metallothionein levels of Barbonymous gonionotus gills in the upstream and downstream of Brantas River is shown in Figure 3. Metallothionein levels of Barbonymous gonionotus gills in the upstream
(Karangkates Reservoir) were not significantly different compared to the ones in the downstream of Brantas River $(p>0,05)$. The highest metallothionein levels of Barbonymous gonionotus gills in the downstream of Brantas River was on March $(0.26 \mathrm{ng} / \mathrm{mL})$ and the lowest in the upstream was on June and September $(0.18 \mathrm{ng} / \mathrm{mL})$.

The different metallothionein levels of Barbonymous gonionotus liver in the upstream and downstream of Brantas River is shown in Figure 4. Metallothionein levels of Barbonymous gonionotus liver in the upstream and downstream of Brantas River were not significantly different. The highest metallothionein level of Barbonymous gonionotus liver in the downstream of Brantas River was on June $(0.45 \mathrm{ng} / \mathrm{mL})$, while the lowest metallothionein level was on March $(0.18 \mathrm{ng} / \mathrm{mL})$.

Table 1. Metallothionein levels of Barbonymus gonionotus in the upstream and downstream of Brantas River

\begin{tabular}{|c|c|c|c|c|c|c|c|}
\hline & & \multicolumn{6}{|c|}{ Metallothionein Level $(\mathrm{ng} / \mathrm{mL}) \pm \mathrm{SD}$} \\
\hline & & \multicolumn{3}{|c|}{ Karangkates Reservoir } & \multicolumn{3}{|c|}{ Kali Jagir River } \\
\hline \multirow{3}{*}{ Gills } & March & 0.18 & \pm & 0.02 & 0.27 & \pm & 0.04 \\
\hline & June & 0.18 & \pm & 0.005 & 0.18 & \pm & 0.01 \\
\hline & September & 0.2 & \pm & 0.02 & 0.18 & \pm & 0.004 \\
\hline \multirow{3}{*}{ Liver } & March & 0.18 & \pm & 0 & 0.2 & \pm & 0.01 \\
\hline & June & 0.18 & \pm & 0.28 & 0.45 & \pm & 0.16 \\
\hline & September & 0.18 & \pm & 0.01 & 0.2 & \pm & 0 \\
\hline
\end{tabular}




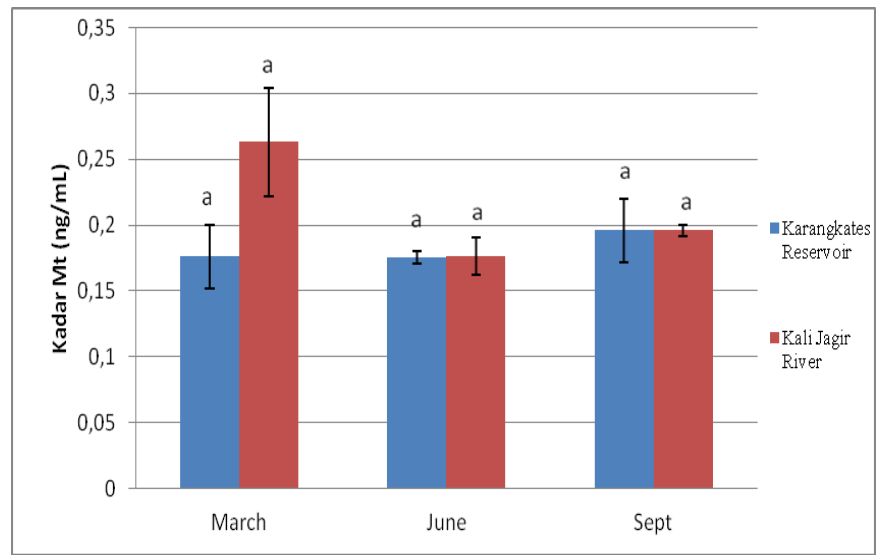

Figure 3. Metallothionein levels of Barbonymus Gonionotus gills in the upstream and downstream of Brantas River

\section{Discussion}

The result of statistical test on the normal gill lamela in Kali Jagir River and Karangkates Reservoir showed that the difference was significant $(\mathrm{P}<0.05)$, so was on edema, hyperplasia, accept for fusion is not significant. This result showed that the fish habitat in the upstream and downstream of Brantas river was almost same, because the upstream (Karangkates Reservoir) was already polluted by industrial, household, and recreational waste.

The present result showed that the highest number of hepatocytes in Kali Jagir River were necrosis hepatocytes. The percentage of necrosis hepatocytes in Kali Jagir River on March showed significant difference compared to necrosis hepatocytes on June and September. Percentage of necrosis hepatocytes on June did not show significant difference compared to necrosis hepatocytes on September. The highest percentage of necrosis hepatocytes was on September $(79,88 \%)$ due to increasing of pollution level in Kali Jagir River on September. The percentage number of necrosis hepatocytes on March $(3,11 \%)$ was lower because of the low level of pollution in Kali Jagir River.

The result of this study showed that there was different result between the metallothionein levels of Barbonymus Gonionotus gills and liver in the upstream and downstream but did not significantly different. A study by Hayati et. al. (2017) stated that the upstream (Karangkates Reservoir) was a reservoir from some small streams. Many places were suspected as the sources of metal in this area, such as reservoir that was used as fresh water aquaculture. Fish feed was source of organic matter binded with metals. Metal was presented in the form of compounds binded to waters and organic matters. Boats fuel and paint were also the source of heavy metals in this area.

The amount of heavy metals in the downstream of Brantas River (Kali Jagir River) was higher than in the upstream because of industrial waste and household waste disposal to the river. Factories and people on the riverbank dispose their waste directly to the river cause

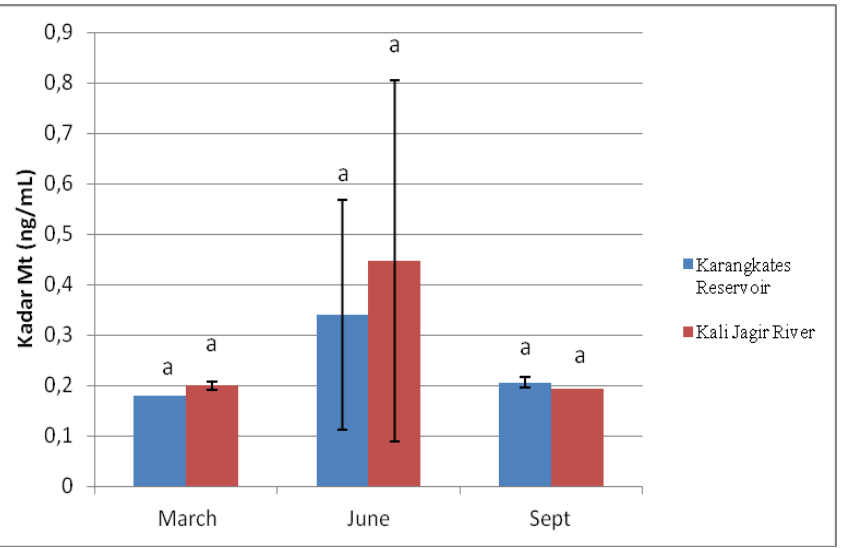

Figure 4. Metallothionein levels of Barbonymus gonionotus liver in the upstream and downstream of Brantas River

heavy metal accumulation in the upstream of Brantas River.

Metallothionein could be used as pollution biomarker due to its sensitivity and accuracy. This is based on the nature phenomenon that metals are trapped in the organism body due to the existence of this protein. As metal-binding protein, metallothioenin has role as metal binder in every organism tissue (Dewi et al., 2014).

The highest metallothionein level was in the liver of Barbonymus gonionotus in the downstream of Brantas River $(0.45 \mathrm{ng} / \mathrm{ml})$. The heavy metals are binded through the gills of fresh water fish, detoxified in the liver and accumulated in other organs. As a detoxification organ, liver produces higher amount of metallothionein. A study by $\mathrm{Wu}$ and Chun (2005) on Raibow trout detected the highest amount of $\mathrm{Cd}$ in the liver and induced the synthesis of MTS and Cd-MT complex.

This present result showed that the average level of metallothionein in the downstream was higher than in the upstream of Brantas River but the difference of metallothionein level in the organ of Barbonymus gonionotus was not significant in the upstream at different times $(p>0,05)$. The highest levels of metallothionein in the downstream of Brantas River were found in the liver on June $(0.45 \mathrm{ng} / \mathrm{mL})$, gills on March $(0.26 \mathrm{ng} / \mathrm{mL})$, liver on March $(0.2 \mathrm{ng} / \mathrm{mL})$, liver on September $(0.19 \mathrm{ng} / \mathrm{ml})$, and gills on June and September $(0.18 \mathrm{ng} / \mathrm{ml})$ respectively . There was no significant difference between the level of metallothionein in the gill and liver of Barbonymus gonionotus at some different points of time.

The different metallothionein level accumulated in the organ depend on the increasing number of metallothionein mRNA in the tissue exposed by metals as response of different metal flow rate in the tissue. The different metallothionein level is also related to other metal-binding protein such as superoxide dismutase (Ginick et al., 2011). Metallothionein was earlywarning biomarker of heavy metals exposure $(\mathrm{Cd}, \mathrm{Pb}$, and $\mathrm{Hg})$ in cellular level, the early reaction before any responses occurred to higher level of biology spectrum (Dewi et al., 2014).

In 2011-2015, the dry season lasted from June to October, while the rainy season lasted on the other months. This pattern was different from the one in 2016 
when rain fell throughout the year. This is because Indonesia, especially Surabaya, is strategically located in the tropic area between two continents (Asia and Australia) and two oceans (Pacific and Hindia), so this region is prone to weather and climate changes. Weather anomaly in 2016/2017 was caused by El Nino, La Nina, and the temperature change of the sea surface. Heavy metal level variance could be related to adsorption, sedimentation, and flocculation that mostly happened in dry season (Ibigbami et al., 2017). The increasing and decreasing level of heavy metals depend on the season change because the water debit was high on rainy season and low in the dry season. The season also effected the level and type of heavy metals, that is $\mathrm{Cu}>\mathrm{Zn}>\mathrm{Fe}>\mathrm{Mn}$

\section{Acknowledgment}

Author would like to thank for DIPA BOPTN Airlangga University which has provided funding in research decentralization activities in 2016.

\section{References}

Authman, Mohammad, MN, Ibrahim, Seham A, El-Kasheif, Gaber, Hanan. (2013). Heavy Metals Pollution and Their Effects on Gills and Liver of the Nile Catfish Clarias gariepinus Inhabiting El-Rahawy Drain, Egypt. Global veterinaria journal. Egypt.

Annabi, Ali, Said, Khaled, Messaouidi. 2013. Cadmium: Bioaccumulation, Histophatology an Detoxifying Mechanism in Fish. American Journal Communication. USA

Chowdhury MJ, Baldisserotto B, Wood CM. Tissue-specific cadmium and metallothionein levels in rainbow trout chronically acclimated to waterborne or dietary cadmium. Arch Environ Contam Toxicol 2005; 48:381-390

Dewi, NK, Purwanto, Sunoko, HR. 2014. Metallothionein in The Fish Liver as Biomarker of Cadmium (Cd) Pollution in Kaligarang River Semarang. Journal Manusia dan Lingkungan, Semarang. Indonesia.

Fatchiyah, Arumningtyas, EL, Widyarti, Sri, Rahayu, Sri. 2011. Biologi Molekular Prinsip Dasar Analisis. Erlangga, Jakarta. Indonesia.

Gonick, Harvey.C. 2011. Lead-Binding Proteins: A review. Hindawi Publishing Corporation. Journal of Toxicology Volume 2011, Article ID 686050.

Hayati, Alfiah, M. Maulana Abdizen, Antien Rekyan Seta, Bint Mar`atus Solikha, Nuril Maulidyah, Nureka Tiantono, Hana Widyana, Inesavira Restinastiti, Deszantara Ziky, Sugiharto, Winarni, Dwi. 2017. Bioaccumulation of Heavy Metals in Fish (Barbodes sp.) Tissues in the Brantas River, Indonesia. Journal of Applied Environmental and Biological Sciences. ISSN: 2090-4274

Hayati, Alfiah, Tiantono, Nureka, Mirza, Muhamad Fadhil Iman Putra, Dary Supriyadi, Abdizen Muhamad Maulana, Seta, Antien Rekyan, Binti Mar`atus Solikha, Muhamad Hilman Fu'adil, Trisnadi Widyaleksono Catur Putranto, Mochamad Affandi, and Rosmanida. 2017. Water quality and fish diversity in the Brantas River, East Java, Indonesia. Journal of Biological Researches. Indonesia.

Ibigbami, OA, Awokunmi E.E, Asaolu, S.S. 2017. Distribution Enrichment and Accumulation of Heavy Metals in Elemi River Sediments, South-Western, Nigeria. IOSR Journal of Environmental Science, Toxicology and Food Technology (IOSR-JESTFT) e-ISSN: 2319-2402,p- ISSN: 23192399. Volume 11, Issue 3 Ver. I (Mar. 2017), PP 57-61

Nedecky, Branislav Ruttkay, Nejdl, Lukas, Gumulec, Jaromir, Zitka, Ondrej Masarik, Michal, Tomas Eckschlager, Marie Stiborova, Vojtech Adam 1,2 and Kizek, Rene. 2013. The Role of Metallothionein in Oxidative Stress. International Journal of Molecular Sciences. ISSN 1422-0067
$>\mathrm{Pb}>\mathrm{Cd}>\mathrm{Cr}$ on dry season and $\mathrm{Cu}>\mathrm{Zn}>\mathrm{Mn}>\mathrm{Pb}>$ $\mathrm{Fe}>\mathrm{Cr}>\mathrm{Cd}$ on rainy season (Gonick et al., 2011).

The highest damage of Barbonymus gonionotus gills lamella in Karangkates Reservoir and Kali Jagir River was hyperplasia, while the highest number of normal hepatocyte cells was found in Karangkates Reservoir and the highest number of necrosis hepatocyte cells was found in kali Jagir River. There was insignificant difference between the metallothionein level of Barbonymus gonionotus gills and liver in the upstream (Karangkates Reservoir) and the downstream (Kali Jagir River) of Brantas River. Different points of time (March, June, September) showed that there was different metallothionein level in each organ (gill and liver).

Priatna, DE, Purnumo, T, Kuswanti, N. 2016. The content of heavy metal lead (PB) in the water and Bader fish (Barbonymus gonionotus) of Brantas River, Mojokerto Region. Journal of Lentera Bio. Universitas Surabaya. Indonesia.

Rochyatun., E., dan Rozak, A. 2007. Pemantauan Kadar Logam Berat Dalam Sedimen Di Perairan Teluk Jakarta, Jurnal Makara Sains, Vol. 11 No. 1 April 2007: 28-36.

Sigel H, Sigel A, eds. 2009. Metallothioneins and Related Chelator (Metal Ions in Life Sciences). Metal Ions in Life Sciences. 5. Cambridge, England: Royal Society of Chemistry. ISBN 1 84755-899-2.

Soegianto, A. 2008. Bioaccumulation of Heavy Metals in Some Commersial Animal

Caught from Selected Coastal Water of East Java, Indonesia. Research Journal of Agriculture and Biological Sciences.

Usman AR. 2003. Comprehensive Development Of The Brantas River Basin The Republic Of Indonesia, Faculty of Engineering, The Brawijaya University, Indonesia.

Wangboje, O, M, Ekundayo, O, T, Ojo Obasuyi. 2013. Heavy Metals In The Myonematic, Hepatic And Renal Tissues Of The African Cat Fish (Clarias Gariepinus) From Ogba River, Benin City, Nigeria. Journal of Agricultural Science and Environment. Nigeria. 